\title{
PENERAPAN KONSEP TRANSIT ORIENTED DEVELOPMENT DALAM PENGEMBANGAN KAWASAN JEMBATAN MERAH SURABAYA
}

\author{
Alethea Jihan Masyithah'1, Sardjito', Ketut Dewi Martha Erli Handayeni1 \\ 1Departemen Perencanaan Wilayah dan Kota, Fakultas Teknik Sipil, Perencanaan, dan Kebumian, Institut Teknologi Sepuluh Nopember
}

\begin{abstract}
Abstrak
Kawasan Jembatan Merah Surabaya merupakan kawasan Kota Lama Surabaya yang masih mempunyai banyak bangunan cagar budaya. Fungsi utama kawasan ini adalah perdagangan dan jasa, serta akan direncanakan menjadi salah satu kawasan pariwisata sejarah di Kota Surabaya. Kawasan ini memiliki titik transit berupa terminal yang melayani moda transportasi angkutan kota (lyn) dan bus kota untuk tujuan dalam maupun luar kota Surabaya. Dalam kebijakan transportasi Surabaya, kawasan ini akan dijadikan sebagai satu dari beberapa kawasan yang akan dikembangkan konsep Transit Oriented Development (TOD). Penelitian ini bertujuan untuk menentukan prioritas pengembangan Kawasan Jembatan Merah Surabaya berdasarkan konsep TOD dengan mempertimbangkan kesesuaian karakteristik kawasan sebagai kawasan Kota Lama Surabaya. Tujuan tersebut dilakukan melalui tiga sasaran. Pertama, menentukan kriteria, indikator dan variabel konsep TOD sesuai dengan karakteristik kawasan Jembatan Merah Surabaya dengan analisis Delphi. Kedua, menentukan prioritas pengembangan kawasan Jembatan Merah berdasarkan konsep TOD dengan Analytical Hierarchy Process (AHP). Ketiga, identifikasi karakteristik kawasan Jembatan Merah Surabaya sesuai dengan kriteria kawasan TOD menggunakan analisis deskriptif statistik. Adapun output dari penelitian ini adalah Prioritas Pengembangan Kawasan Jembatan Merah Surabaya berdasarkan Konsep TOD. Berdasarkan hasil penelitian, diperoleh sebelas variabel yang berpengaruh terhadap pembentukan kawasan Jembatan Merah Surabaya berdasarkan konsep TOD. Urutan variabel berpengaruh menurut prioritas pengembangannya, yakni: Penggunaan Lahan Non-Residensial; Ketersediaan Jalur Pedestrian; Kondisi Jalur Pedestrian; Kondisi Bangunan; Konektivitas Jalur Pedestrian; Dimensi Jalur Pedestrian; Ketersediaan Penyebrangan Pedestrian; KLB (Koefisien Lantai Bangunan); KDB (Koefisien Dasar Bangunan); Kepadatan Bangunan dan Penggunaan Lahan Residensial. Dengan mengacu pada hasil tersebut, diidentifikasi pula tingkat kesesuaian dari karakteristik kawasan Jembatan Merah Surabaya dengan kriteria TOD.
\end{abstract}

Kata kunci: kawasan Jembatan Merah Surabaya; kawasan tansit; Kota Lama Surabaya; pengembangan kawasan; Transit Oriented Development

\begin{abstract}
Jembatan Merah Surabaya is located in the old city area of Surabaya, which still has many cultural heritage buildings. The main function of this area is a trade and services area, and is planned to become one of the historical tourism areas in Surabaya CityThis area has a transit point in the form of a terminal that serves the city transportation mode (lyn) and city buses for destinations inside and outside the city of Surabaya. In Surabaya's transportation policy, the Transit Oriented Development (TOD) concept will be developed in this area. . This study aims to determine priorities for the development of the Jembatan Merah area in Surabaya based on the TOD concept by considering the suitability of the area's characteristics as the old city of Surabaya. This goal is carried out through three targets. First, determining the criteria, indicators and variables of the TOD concept according to the characteristics of the Jembatan Merah Area in Surabaya using the Delphi analysis. Second, determining the development priority for the Jembatan Merah area based on the TOD concept with the Analytical Hierarchy Process (AHP). Third, identifying the characteristics of the Jembatan Merah area in Surabaya according to the criteria for the TOD area using statistical descriptive analysis. The results of this research are the Jembatan Merah Area Development Priority based on the TOD Concept. The results show that there are eleven variables that influence the formation of Jembatan Merah Surabaya area based on the TOD concept. The order of variables influences according to the priority of their development is Non Residential Land Use; Availability of Pedestrian Lane; Pedestrian Lane Conditions; Building Condition; Pedestrian Lane Connectivity; Pedestrian Lane Dimension; Availability of Pedestrian Crossings ; Floor Area Ratio (FAR); Building Coverage Area (BCA) ; Building density; and Residential Land Use.By considering these results, the level of suitability of the characteristics of the Red Bridge Area in Surabaya with the TOD criteria was also identified.
\end{abstract}

Keywords: area development; Jembatan Merah Surabaya Area; Surabaya Old Town; transit area; Transit Oriented Development 


\section{PENDAHULUAN}

Salah satu permasalahan akan transportasi adalah kemacetan. Beberapa penyebab kemacetan adalah adanya keterbatasan sarana prasarana transportasi, rendahnya kesadaran akan disiplin lalu lintas, pesatnya urbanisasi dan sistem perencanaan transportasi yang kurang baik. Permasalahan kemacetan tidak hanya bisa diselesaikan dengan supply jaringan jalan dan angkutan umum, namun juga harus diintegrasikan dengan sebaran pusat-pusat kegiatan kota dan sistem transportasi yang melayani kawasan tersebut.

Terdapat banyak jenis konsep penanganan kemacetan yang bisa diterapkan. Salah satunya adalah konsep Transit Oriented Development (TOD). Konsep ini menjunjung strategi inovatif dalam pengintegrasian transportasi perkotaan dengan penggunaan lahan. Dengan adanya integrasi yang baik antara dua hal tersebut, akan membentuk suatu kawasan yang dapat mengurangi kebutuhan untuk berpergian menggunakan kendaraan pribadi dan mulai menggunakan kendaraan umum.

Pemerintah Kota Surabaya yakni Bappeko Surabaya telah melakukan studi tentang penerapan konsep TOD dalam penataan Kota Surabaya, bahwa konsep ini berpotensi untuk diterapkan dalam arahan penataan struktur ruang Kota Surabaya. Dalam dokumen Surabaya Mass Rapid Transport (SMART) dinyatakan bahwa akan dikembangkan beberapa kawasan dengan konsep TOD di Surabaya, yang salah satunya adalah kawasan Jembatan Merah Surabaya (Bappeko Surabaya, 2018).

Kawasan Jembatan Merah merupakan kawasan kota lama di Surabaya yang memiliki banyak bangunan-bangunan peninggalan kolonial. Sebagai kawasan yang fokus pada kegiatan perdagangan jasa, kawasan ini memiliki intensitas kegiatan yang cukup tinggi. Dengan adanya intensitas kegiatan yang tinggi, maka konsentrasi pergerakan di kawasan Jembatan Merah juga tinggi. Hal ini sejalan dengan pernyataan dari ITDP (2017) bahwa intensitas kegiatan tinggi merupakan salah satu ciri karakteristik kawasan TOD. Kawasan Jembatan Merah memiliki Terminal Jembatan Merah sebagai salah satu titik transitnya. Terminal Jembatan Merah merupakan terminal yang melayani transportasi umum untuk angkutan perkotaan, yakni bus kota dan juga mikrolet atau yang juga biasa disebut lyn di Surabaya. Selain itu, kawasan Jembatan Merah ini juga dilayani oleh Suroboyo Bus dengan dua titik pemberhentian atau halte yang ada di Jalan Rajawali, yakni Halte Rajawali dan Halte Jembatan Merah.

Meskipun begitu, potensi yang ada pada kawasan Jembatan Merah Surabaya ini dirasa belum dimaksimalkan oleh Kota Surabaya. Sebagai kawasan perdagangan dan jasa, kawasan ini juga memiliki permasalahan dalam hal parkir dan jalur pedesterian. Hal inilah yang menyebabkan kawasan tersebut dianggap masih belum memenuhi kriteria walkable. Kondisi eksisting kawasan yang demikian sangat disayangkan karena terdapat banyak potensi kawasan yang tidak diimbangi dengan penyediaan infrastruktur yang baik. Adanya kebijakan Pemerintah Kota Surabaya untuk mengembangkan kawasan Jembatan Merah Surabaya dengan konsep TOD sangatlah tepat untuk dijadikan salah satu solusi menangani permasalahan di kawasan tersebut. Konsep TOD ini juga bisa digunakan sebagai tools untuk melestarikan bangunan cagar budaya yang terdapat pada sekitar kawasan transit, sehingga pengembangan konsep TOD ini juga harus memperhatikan hal tersebut. Maka, diperlukan adanya penelitian untuk mengetahui variabel apa saja yang berpengaruh dalam pengembangan konsep TOD di kawasan Jembatan Merah Surabaya serta prioritas dalam pengembangannya dengan memperhatikan tingkat kesesuaiann karakteristik kawasan terhadap konsep TOD. Hal ini dimaksudkan untuk mengetahui prioritas pengembangan kawasan serta gap dalam proses pengembangan, sehingga pengembangan nantinya dapat membentuk kawasan yang sesuai dengan konsep TOD yang terstruktur dan sesuai dengan kebutuhan pengembangan.

Tujuan penelitian ini akan dijawab melalui tiga sasaran. Sasaran pertama, yakni menentukan kriteria, indikator, dan variabel konsep TOD yang sesuai dengan karakteristik kawasan Jembatan Merah Surabaya menggunakan analisis Delphi. Sasaran kedua adalah menentukan prioritas pengembangan kawasan Jembatan Merah berdasarkan konsep TOD dengan Analytical Hierarchy Process (AHP). Serta sasaran ketiga adalah identifikasi karakteristik kawasan Jembatan Merah Surabaya sesuai dengan kriteria kawasan TOD menggunakan analisis deskriptif statistik. 


\section{KAJIAN PUSTAKA}

\subsection{TRANSIT ORIENTED DEVELOPMENT}

\subsubsection{Definisi Transit Oriented Development}

Transit Oriented Development (TOD) merupakan suatu pendekatan dalam pengembangan kota dengan konsep memadukan desain ruang kota yang bertujuan untuk mengintegrasikan orang, kegiatan, bangunan, dan publik space yang dihubungkan dengan jalur pedestrian dan jalur sepeda serta terjangkau oleh pelayanan angkutan umum ke seluruh kota-kota (ITDP, 2017). Dalam pengembangan tata guna lahannya, konsep TOD menekankan pada pengembangan mixed-use dengan kepadatan yang tinggi di sekitar kawasan yang masih bisa dijangkau dengan berjalan kaki, sehingga terciptalah lingkungan dimana setiap orang dapat berjalan, hidup, bekerja, berbelanja, dan bermain dengan aman (Winkelman, 2014). Adanya penggunaan lahan campuran atau mixed-use seperti menempatkan fasilitas umum, kantor, toko retail, dan perumahan di sekitar titik transit akan mendorong orang untuk menggunakan transportasi umum dan mengurangi penggunaan kendaraan bermotor. Cervero dan Day (2018) juga telah melakukan penelitian bahwa pada kawasan penerapan TOD di Shanghai terdapat peningkatan penggunaan angkutan umum dan akses ke pekerjaan regional. Hal ini membuktikan bahwa adanya penerapan konsep TOD ini telah berhasil memberikan dampak terhadap pola perjalanan.

\subsubsection{Karakteristik Kawasan Transit Oriented Development}

Pada Florida TOD Giuidebook (2012), kawasan TOD mempunyai radius $1 / 4-1 / 2$ mil atau setara dengan 400-800 meter dari titik transit yang dapat ditempuh dengan waktu 5-10 menit dengan berjalan kaki. Begitupula pada Permen ATR/KaBPN No. 16 Tahun 2017 tentang Pedoman Pengembangan Kawasan Berorientasi Transit, radius kawasan TOD juga sebesar 400 meter sampai 800 meter dari simpul transit moda angkutan umum massal. Selain ketentuan mengenai radius pengembangan untuk kawasan TOD, berikut merupakan beberapa karakteristik yang menjadi faktor utama untuk menciptakan kawasan TOD. Tabel 1 merupakan beberapa indikator dan variabel Kawasan TOD dari beberapa sumber.

Tabel 1. Indikator dan Variabel Pengembangan Kawasan TOD

\begin{tabular}{|c|c|c|}
\hline Permen ATR/KaBPNNo. 16 Tahun 2017 & Florida TOD Guidebook (2012) & Calthrope Associate (2011) \\
\hline $\begin{array}{c}\text { Diversity (Campuran dan Keragaman } \\
\text { Pemanfaatan Ruang) }\end{array}$ & $\begin{array}{l}\text { Indikator } \\
\text { Mix Use }\end{array}$ & Mix Use \\
\hline $\begin{array}{l}\text { Aktivitas Signifikan di Kawasan } \\
\text { Penggunan Lahan Residensial dan Non } \\
\text { Residensial } \\
\text { Jenis Kegiatan Pemanfaatan Ruang }\end{array}$ & $\begin{array}{l}\text { Penggunan Lahan Residensial } \\
\text { Penggunan Lahan Non Residensial }\end{array}$ & $\begin{array}{l}\text { Penggunan Lahan Residensial } \\
\text { Penggunaan Lahan Komersial } \\
\text { Penggunaan Lahan Faislitas Umum }\end{array}$ \\
\hline $\begin{array}{l}\text { Karakteristik Komersial } \\
\text { Tipe Hunian } \\
\text { Target Unit Hunian }\end{array}$ & & Penggunana Lahan Perkantoran \\
\hline Density (Kepadatan) & Density & Density \\
\hline $\begin{array}{l}\text { Kepadatan Penduduk } \\
\text { Kepadatan Pekerja } \\
\text { KLB } \\
\text { Pola Kepadatan } \\
\text { Kepadatan Hunian } \\
\text { Jumlah Lantai } \\
\text { KDB } \\
\text { Street Frontage } \\
\text { Ruang Terbuka } \\
\text { Tipologi Ruang Terbuka }\end{array}$ & $\begin{array}{l}\text { FAR (KLB) } \\
\text { BCR (KDB) } \\
\text { Kepadatan Pekerjaan } \\
\text { Total pekerjaan } \\
\text { Rasio Pekerjaan: Hunian } \\
\text { Kepadatan Bangunan }\end{array}$ & $\begin{array}{l}\text { KDB } \\
\text { KLB } \\
\text { Kepadatan Penggunaan Lahan }\end{array}$ \\
\hline Street Design (Parkir) & Design (Jalur Pedestrian) & Building Siting and Design \\
\hline $\begin{array}{l}\text { Batas Parkir Hunian } \\
\text { Batas Parkir Perkantoran }\end{array}$ & $\begin{array}{l}\text { Lebar Jalur Pedestrian } \\
\text { Minimum Kanopi }\end{array}$ & $\begin{array}{l}\text { Building Entries } \\
\text { Building Design (Façade) }\end{array}$ \\
\hline
\end{tabular}




\begin{tabular}{|c|c|c|}
\hline Permen ATR/KaBPNNo. 16 Tahun 2017 & Florida TOD Guidebook (2012) & Calthrope Associate (2011) \\
\hline \multicolumn{3}{|c|}{ Indikator } \\
\hline Batas Parkir Lantai Dasar & & Street and Circulation System \\
\hline Pola Parkir & & Dimensi Jalan \\
\hline Park and Ride & & Pola Jaringan jalan \\
\hline Sistem Transit & & Pedestrian and Bicycle System \\
\hline Pengembangan moda transit & & Jalur Pedestrian \\
\hline Pola Jaringan Jalan & & Jalur Sepeda \\
\hline Dimensi Blok & & Fasilitas parkir sepeda \\
\hline Pola Jaringan & & \\
\hline
\end{tabular}

\subsection{PELESTARIAN BANGUNAN CAGAR BUDAYA}

Menurut Undang-Undang Republik Indonesia No. 11 Tahun 2010, cagar budaya diartikan sebagai warisan budaya yang bersifat kebendaan berupa Benda Cagar Budaya, Bangunan Cagar Budaya, Struktur Cagar Budaya, Situs Cagar Budaya, dan Kawasan Cagar Budaya di darat dan/atau di air yang perlu dilestarikan keberadaannya karena memiliki nilai penting bagi sejarah, ilmu pengetahuan, pendidikan, agama, dan/atau kebudayaan melalui proses penetapan. Pelestarian sendiri diartikan sebagai upaya dinamis untuk mempertahankan keberadaan cagar budaya dan nilainya dengan cara melindungi, mengembangkan, dan memanfaatkannya.

Dalam Perda Kota Surabaya Nomor 5 Tahun 2005, konservasi atau pelestarian bangunan cagar budaya adalah segala proses pengelolaan bangunan dan/atau lingkungan cagar budaya agar makna budaya yang dikandungnya terpelihara dengan baik dengan tujuan untuk melindungi, memelihara dan memanfaatkan, dengan cara preservasi, pemugaran atau demolisi.

Dalam upaya pelestariannya, bangunan cagar budaya dibagi dalam 4 (empat) golongan, yaitu bangunan cagar budaya Golongan A, Golongan B, Golongan C, dan Golongan D. Dari tiap golongan tersebut, ketentuan dalam pelaksanaan pelestarian bangunan cagar budayanya juga akan berbeda.

1. Bangunan cagar budaya Golongan A adalah bangunan cagar budaya yang harus dipertahankan dengan cara preservasi.

2. Bangunan cagar budaya Golongan $B$ adalah bangunan cagar budaya yang dapat dilakukan pemugaran dengan cara restorasi/rehabilitasi atau rekonstruksi.

3. Bangunan cagar budaya Golongan $\mathrm{C}$ adalah bangunan cagar budaya yang dapat dilakukan pemugaran dengan cara revitalisasi/adaptasi.

4. Bangunan cagar budaya Golongan $D$ adalah bangunan cagar budaya yang keberadaannya dianggap dapat membahayakan keselamatan pengguna maupun lingkungan sekitarnya, sehingga dapat dibongkar dan dapat dibangun kembali sesuai dengan aslinya dengan cara demolisi.

Tabel 2 merupakan penjelasan mengenai ketentuan pelestarian bangunan cagar budaya berdasarkan golongannya menurut Peraturan Daerah Kota Surabaya Nomor 5 Tahun 2005.

Tabel 2. Ketentuan Pelestarian Bangunan Cagar Budaya Berdasarkan Golongan

\begin{tabular}{|c|c|c|c|}
\hline No & $\begin{array}{c}\text { Golongan } \\
\text { Cagar } \\
\text { Budaya }\end{array}$ & $\begin{array}{c}\text { Jenis } \\
\text { Pelestarian }\end{array}$ & Ketentuan \\
\hline 1. & $A$ & Preservasi & $\begin{array}{l}\text { a. Bangunan dilarang dibongkar dan/atau diubah } \\
\text { b. Apabila kondisi fisik bangunan buruk, roboh, terbakar atau tidak layak berdiri, dapat } \\
\text { dilakukan pembongkaran untuk dibangun kembali seperti semula sesuai dengan aslinya } \\
\text { c. Pemeliharaan dan perawatan bangunan harus menggunakan bahan yang sama/sejenis } \\
\text { atau memiliki karakter yang sama dengan mempertahankan detail ornamen aslinya } \\
\text { d. Dalam upaya revitalisasi dimungkinkan adanya penyesuaian perubahan fungsi sesuai } \\
\text { rencana kota yang berlaku tanpa mengubah bentuk aslinya } \\
\text { e. Di dalam persil atau lahan bangunan cagar budaya dimungkinkan adanya bangunan } \\
\text { tambahan yang menjadi satu kesatuan yang utuh dengan bangunan utama }\end{array}$ \\
\hline
\end{tabular}




\begin{tabular}{|c|c|c|c|}
\hline No & $\begin{array}{c}\text { Golongan } \\
\text { Cagar } \\
\text { Budaya }\end{array}$ & $\begin{array}{c}\text { Jenis } \\
\text { Pelestarian }\end{array}$ & Ketentuan \\
\hline 2. & $B$ & $\begin{array}{l}\text { Pemugaran } \\
\text { (Restorasi// } \\
\text { Rehabilitasi/ } \\
\text { Rekonstruksi) }\end{array}$ & $\begin{array}{l}\text { a. Bangunan dilarang dibongkar kecuali apabila kondisi fisik bangunan buruk, roboh, } \\
\text { terbakar atau tidak layak tegak, sehingga dapat dilakukan pembongkaran } \\
\text { b. Dalam hal bangunan cagar budaya sudah tidak utuh lagi maka apabila dilakukan } \\
\text { pembangunan harus sesuai dengan bentuk aslinya dan tidak boleh membongkar bagian } \\
\text { bangunan yang masih ada } \\
\text { c. Pemeliharaan dan perawatan bangunan cagar budaya harus dilakukan tanpa mengubah } \\
\text { tampang bangunan, warna dan detail serta ornamen bangunan } \\
\text { d. Dalam upaya restorasi/rehabilitasi atau rekonstruksi dimungkinkan adanya perubahan tata } \\
\text { ruang bagian dalam, sepanjang tidak mengubah struktur utama bangunan } \\
\text { e. Di dalam persil atau lahan bangunan cagar budaya dimungkinkan adanya bangunan } \\
\text { tambahan yang menjadi satu kesatuan yang utuh dengan bangunan utama }\end{array}$ \\
\hline 3. & $C$ & $\begin{array}{l}\text { Pemugaran } \\
\text { (Revitalisasi/ } \\
\text { Adaptasi) }\end{array}$ & $\begin{array}{l}\text { a. Perubahan bangunan dapat dilakukan dengan syarat tetap mempertahankan tampang } \\
\text { bangunan utama termasuk warna, detail dan ornamennya } \\
\text { b. Warna, detail dan ornamen dari bagian bangunan yang diubah disesuaikan dengan } \\
\text { arsitektur bangunan aslinya } \\
\text { c. Penambahan bangunan di dalam tapak atau persil hanya dapat dilakukan di belakang } \\
\text { bangunan cagar budaya dan harus disesuaikan dengan arsitektur bangunan cagar } \\
\text { budaya dalam keserasian tatanan tapak } \\
\text { d. Fungsi bangunan dapat diubah sesuai dengan rencana kota }\end{array}$ \\
\hline 4. & $\mathrm{D}$ & $\begin{array}{l}\text { Dibongkar/ } \\
\text { Dibangun } \\
\text { Kembali } \\
\text { (Demolisi) }\end{array}$ & $\begin{array}{l}\text { Demolisi merupakan pembongkaran atau perombakan suatu bangunan cagar budaya yang } \\
\text { sudah dianggap rusak dan membahayakan dengan pertimbangan dari aspek keselamatan dan } \\
\text { keamanan dengan melalui penelitian terlebih dahulu dengan dokumentasi yang lengkap. } \\
\text { Ketentuan lebih lanjut mengenai prosedur dan tata cara pelaksanaan demolisi sebagaimana } \\
\text { dimaksud diatur dengan Peraturan Kepala Daerah. }\end{array}$ \\
\hline
\end{tabular}

Sumber: Peraturan Daerah Kota Surabaya Nomor 5 Tahun 2005

\subsection{PENGEMBANGAN KONSEP TOD DI KAWASAN KOTA LAMA}

Kawasan transit seringkali berlokasi di kawasan kota lama yang memiliki banyak bangunan cagar budaya di dalamnya. Menurut Renne dan Listokin (2016), pengembangan konsep TOD dan preservasi bangunan cagar budaya merupakan hal yang bersifat komplementer (saling melengkapi). Dalam waktu bersamaan, kedua hal ini memiliki opportunity dan tension dalam pengembangannya. Opportunity (kesempatan) yang bisa didapatkan antara lain:

1. Preserve History

Dalam pengembangan TOD, bangunan sejarah (bangunan cagar budaya) dapat dimanfaatkan sebagai salah satu aset yang memiliki keunikan tersendiri karena sejarahnya.

2. Draws New Tenants and Promotes Transit Use

Pengembangan kembali bangunan cagar budaya di sekitar kawasan transit dapat menarik para pelaku pergerakan dan tenant.

3. Set the Area's style

Sifat "sensitf" dari bangunan cagar budaya dapat menjadi salah satu pedoman dalam pengembangan TOD, salah satunya adalah pedoman atau batasan mengenai densitas bangunan pada kawasan TOD.

Sedangkan tension (tekanan) yang kemungkinan dihasilkan, yaitu:

1. Restrict the Area's style Pengembang bangunan pada kawasan TOD dibatasi oleh gaya bangunan yang ada.

2. Poses Business Challenges

Preservasi bangunan cagar budaya sulit diimplementasikan karena berapa hal, seperti aspek finansial, regulasi mengenai bangunan cagar budaya dan lain-lain.

Pada intinya, konsep TOD sendiri sebenarnya dapat digunakan sebagai alat untuk merevitalisasi bangunan cagar budaya di sekitar kawasan transit, para pengembang biasanya mengubahnya menjadi kawasan komersial dan lain-lain. Sebaliknya, 
kawasan dengan nilai historik yang memiliki keunikan tinggi dapat menjadi daya tarik di kawasan ini. Antara pengembangan konsep TOD dengan upaya preservasi kawasan kota lama merupakan hal yang bersifat komplementer (saling melengkapi). Namun, ada permasalahan yang muncul ketika konsep TOD yang menekankan pada pengembangan kawasan dengan kepadatan tinggi sekitar kawasan transit, sedangkan penghancuran bangunan cagar budaya untuk memberikan ruang pengembangan kepadatan tinggi ini tidak selalu bisa dilakukan, mengingat terdapat peraturan yang membatasi perlakuan terhadap bangunan cagar budaya. Maka dari itu perlu adanya tool yang dapat menyeimbangkan antara pengembangan kawasan dengan konsep TOD pada kawasan kota lama dengan tidak mengabaikan kondisi bangunan cagar budaya yang seharusnya juga dilindungi.

\section{METODE PENELITIAN}

Pada penelitian ini, penulis memakai pendekatan penelitian rasionalistik yang dilakukan dengan metode pendekatan theoretical analytic dan empirical analytic. Sedangkan jenis penelitian yang dilakukan adalah penelitian deskriptif kualitatif dan kuantitatif. Metode pengumpulan data pada penelitian terdiri dari dua jenis, yakni metode pengumpulan data primer dan metode pengumpulan data sekunder. Pengumpulan data primer dilakukan melalui wawancara dan kuesioner terhadap para stakeholder terpilih dan juga observasi lapangan untuk mengetahui karakteristik kawasan. Sedangkan pengumpulan data sekunder dilakukan dengan cara survey instansi dan survey literatur untuk mendapatkan dokumen serta literatur mengenai konsep TOD.

Tabel 3. Indikator, Variabel dan Parameter Kawasan berdasarkan Konsep TOD

\begin{tabular}{lll}
\multicolumn{1}{c}{ Indikator } & \multicolumn{1}{c}{ Variabel } & \multicolumn{1}{c}{ Parameter } \\
\hline $\begin{array}{l}\text { Density (Kepadatan } \\
\text { Kawasan) }\end{array}$ & KDB (Koefisien Dasar Bangunan) & $\begin{array}{l}\text { Minimal 70\% (khusus bangunan cagar budaya, harus memperhatikan } \\
\text { golongannya) } \\
\text { Minimal 3,0 (khusus bangunan cagar budaya, memperhatikan } \\
\text { golongannya) } \\
450-1500 \text { jiwa/hektar }\end{array}$ \\
& KLB (Koefisien Lantai Bangunan) & \\
& Kepadatan Bangunan & $\begin{array}{l}30 \% \text { dari luas kawasan } \\
70 \% \text { dari luas kawasan }\end{array}$ \\
\hline $\begin{array}{l}\text { Diversity (Penggunaan } \\
\text { Lahan Bercampur) }\end{array}$ & $\begin{array}{l}\text { Penggunan Lahan Residensial } \\
\text { Penggunan Lahan Non- }\end{array}$ & \\
\hline Resign (Pedestrian & Ketersediaan Jalur Pedestrian & Ketersediaan jalur Pedestrian 100\% \\
Friendly). & Kondisi Jalur Pedestrian & Tersedia fasilitas penerangan dan bollard, fasilitas peneduh, dan tactile \\
& Dimensi Jalur Pedestrian & Minimal 2 meter \\
& Konektivitas Jalur Pedestrian & Waktu tempuh 5-10 menit dari titik transit \\
& Ketersedaan Penyebrangan & Bebas pembatas, lebar minimal 2 meter \\
& Pedestrian & Bangunan memiliki ciri, kondisi fisik baik dan fasad bervariasi \\
\hline
\end{tabular}

Sumber: Permen ATR/KaBPN No. 16 Tahun 2017, Peraturan Menteri PU No.3 Tahun 2014, Florida TOD Guidebook (2012), Winnipeg TOD Handbook (2011), ITDP (2017), Winkelman (2014), Watson (2003), Dittmar dan Ohland (2004), Curtis (2009)

Tahap awal atau sasaran 1 yang dilakukan adalah mengidentifikasi kriteria, faktor dan variabel konsep TOD yang sesuai dengan karakteristik kawasan penelitian dengan memakai pendekatan Delphi. Pendekatan dengan metode Delphi ini digunakan untuk mendapatkan konsensus dari pendapat para ahli (stakeholder) terpilih. Pendekatan Delphi ini dilakukan melalui penyebaran kuesioner dan wawancara terhadap lima stakeholder terpilih dari hasil stakeholder analysis, yakni Badan Perencanaan Pembangunan Kota Surabaya (Bappeko), Dinas Perumahan Rakyat dan Kawasan Permukiman, Cipta Karya dan Tata Ruang Kota Surabaya (DPRKP-CKTR), Dinas Perhubungan Kota Surabaya (Dishub), Dinas Pariwisata dan Kebudayaan Kota Surabaya (Disbudpar), serta satu akademisi, yakni dosen transportasi dari Departemen Teknik Sipil ITS. Pihak-pihak tersebut terpilih karena dianggap memiliki pengaruh dan kepentingan dalam pengembangan kawasan Jembatan Merah Surabaya menggunakan konsep TOD. Menurut beberapa sumber literatur, yakni Permen ATR/KaBPN No. 16 Tahun 2017, Florida TOD Guidebook (2012) dan Calthrope Associate (2011), dapat disimpulkan bahwa terdapat tiga indikator umum dalam pengembangan kawasan dengan konsep TOD, yakni Density (Kepadatan Kawasan), Diversity (Penggunaan Lahan Bercampur), dan Design (Pedestrian Friendly). Tiga indikator tersebut kemudian dijabarkan menjadi sebelas variabel (lihat Tabel 3) yang digunakan sebagai input analisis Delphi ini. 
Pada sasaran selanjutnya yakni sasaran 2, dilakukan penentuan prioritas indikator dan variabel pengembangan kawasan penelitian menggunakan konsep TOD menggunakan Analisis AHP (Analytical Hierarchy Process). Metode AHP dipilih untuk mengetahui seberapa penting dan diinginkannya variabel tersebut menurut para ahli dari bobot yang akan dihitung nantinya. Input dari analisis ini merupakan hasil dari analisis Delphi pada tahap sebelumnya (sasaran 1).

Setelah itu pada sasaran terakhir yakni sasaran 3, dilakukan analisis deskriptif statistik untuk menentukan kesesuain karakteristik dan menghitung nilai kesesuaian kawasan penelitian dengan membandingkan kondisi eksisting dan kriteria konsep TOD yang telah dihasilkan dari analisis Delphi pada sasaran 1.

\section{HASIL DAN PEMBAHASAN}

\subsection{GAMBARAN UMUM}

Lingkup area penelitian merupakan kawasan yang memiliki radius 800 meter (ketentuan radius TOD) dari titik transit yang merupakan Terminal Jembatan Merah. Luas total wilayah penelitian adalah 1.704.138,33 $\mathrm{m}^{2}$ atau 170,41 ha. Kawasan Jembatan Merah Surabaya merupakan kawasan kota lama yang potensial karena penggunaan lahannya yang mix use. Fungsi yang paling menonjol di sekitar kawasan Rajawali antara lain fungsi perdagangan dan jasa. Pada kawasan ini juga terdapat perkantoran, fasilitas umum, industri, pergudangan dan permukiman (Gambar 1). Dalam RDTRK UP V Tanjung Perak, kawasan yang tergolong ke dalam kawasan Kota Lama Surabaya ini telah diarahkan sebagai pusat perdagangan dan jasa serta kawasan pariwisata budaya maupun buatan dengan memanfaatkan banguan-bangunan cagar budaya yang ada. Terdapat 3 golongan bangunan cagar budaya pada kawasan Jembatan Merah, yakni bangunan cagar budaya golongan A, B, dan C (Gambar 2).

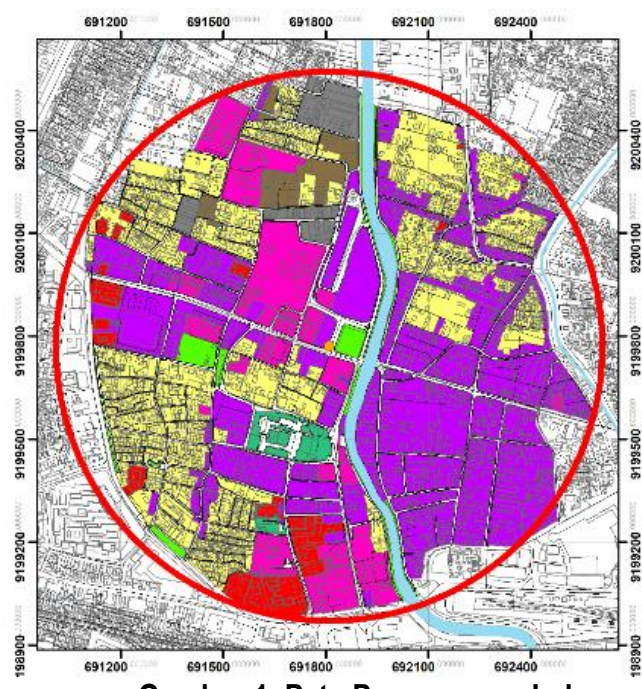

LEGENDA
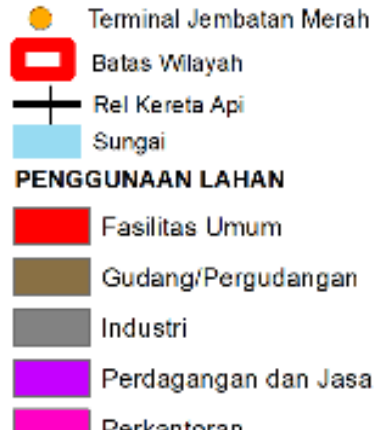

Gambar 1. Peta Penggunaan Lahan pada Wilayah Penelitian 


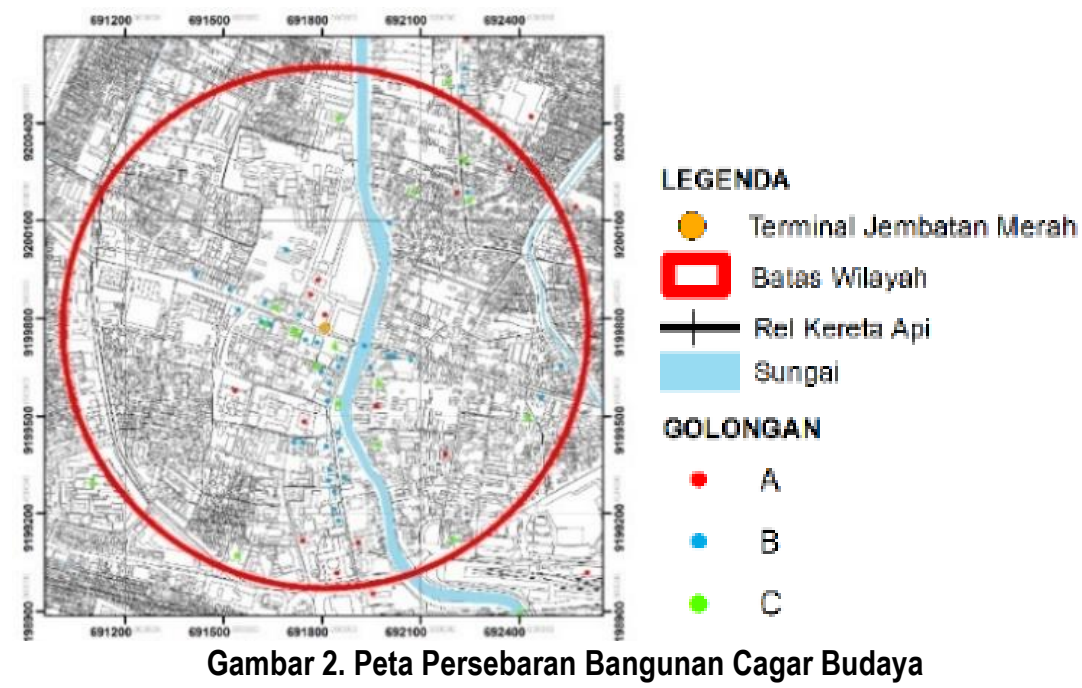

Dalam penelitian, wilayah penelitian akan dibagi menjadi empat blok berdasarkan adanya batas fisik, aksesibilitas kawasan, dan perbedaan karakteristik berdasarkan sejarahnya (Gambar 3).

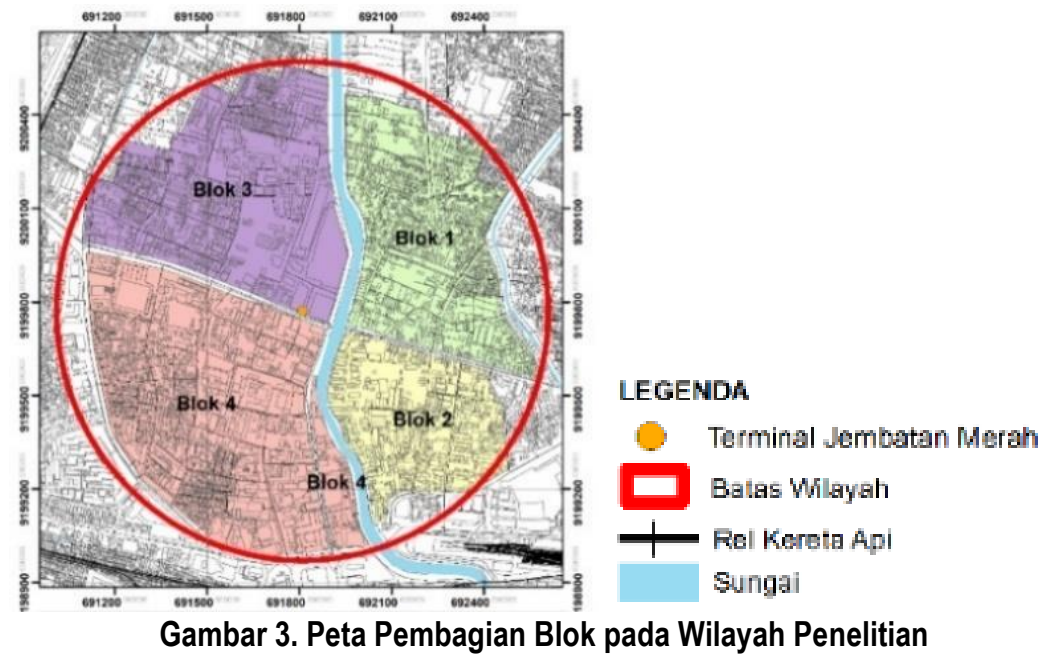

\subsection{KRITERIA, INDIKATOR DAN VARIABEL KONSEP TOD YANG SESUAI DENGAN KARAKTERISTIK KAWASAN JEMBATAN MERAH SURABAYA}

Tabel 4. Hasil Analisis Delphi

\begin{tabular}{cc}
\hline No & Variabel \\
\hline 1 & KDB (Koefisien Dasar Bangunan) \\
2 & KLB (Koefisien Lantai Bangunan) \\
3 & Kepadatan Bangunan \\
4 & Penggunan Lahan Residensial \\
5 & Penggunan Lahan Non-residensial \\
6 & Ketersediaan Jalur Pedestrian \\
7 & Kondisi Jalur Pedestrian \\
8 & Dimensi Jalur Pedestrian \\
9 & Konektivitas Jalur Pedestrian \\
10 & Ketersedaan Penyebrangan Pedestrian \\
11 & Kondisi Bangunan \\
\hline
\end{tabular}


Dari hasil analisis Delphi yang telah dilakukan pada 5 stakeholder terpilih, ternyata semua variabel yang didapatkan dari studi literatur dianggap penting dalam pengembangan konsep TOD pada kawasan Jembatan Merah Surabaya, termasuk variabel "Kondisi Bangunan". Variabel ini telah terkonfirmasi "berpengaruh" khususnya terhadap citra kawasan. Variabel kondisi bangunan ini dipertimbangkan karena kawasan Jembatan Merah Surabaya memiliki potensi utama, yakni bangunan cagar budayanya. Berikut merupakan 11 variabel yang akan digunakan dalam penelitian (lihat Tabel 4).

\subsection{PRIORITAS PENGEMBANGAN KAWASAN JEMBATAN MERAH SURABAYA BERDASRKAN KONSEP TOD}

Pada tahap ini dilakukan analisis untuk menentukan prioritas dari indikator dan juga variabel yang dihasilkan pada sasaran 1 dengan memakai expert choice. Berikut merupakan output dari pembobotan indikator dan variabel penelitian.

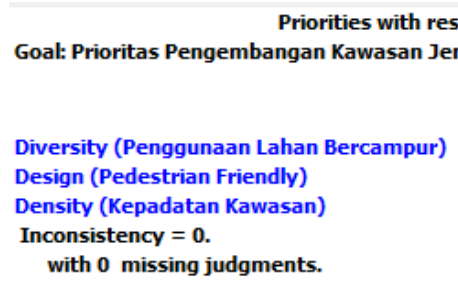

Combined

Gambar 4. Indikator Prioritas untuk Pengembangan Kawasan Jembatan Merah Surabaya Menggunakan Konsep TOD

Dari hasil analisis AHP yang telah dilakukan, dihasilkan urutan indikator prioritas dalam pengembangan kawasan Jembatan Merah Surabaya (Gambar 4). Indikator yang merupakan prioritas tertinggi adalah indikator Diversity (Penggunaan Lahan Campuran) dengan bobot 0,408 atau 40,8\%, lalu indikator Design (Pedestrian Friendly) dengan bobot 0,376 atau 37,6\%, dan yang terakhir adalah indikator Density (Kepadatan Kawasan) dengan bobot 0,216 atau 21,6\%. Dapat disimpulkan bahwasannya Indikator Penggunaan Lahan Campuran (Diversity) memiliki bobot tertinggi. Para stakeholder berpendapat bahwa indikator diversity ini sangat penting karena aktivitas guna lahan di kawasan transit sangat banyak sehingga memberikan kesan mix use yang sangat berpengaruh terhadap bangkitan dan tarikan serta demand penumpang yang akan menggunakan transportasi publik di kawasan transit kelak. Untuk indikator Design, yang berada pada urutan prioritas kedua juga dinilai sangat berpengaruh. Dalam hal ini, indikator design berpengaruh untuk menciptakan kawasan yang walkable dengan ditunjang oleh visual kawasan yang menarik. Sedangkan untuk indikator density dinilai berpengaruh dalam meningkatkan demand transportasi, karena semakin padat kawasan maka semakin banyak pula distribusi perjalanan pada kawasan.

Setelah dihasilkan bobot dari masing-masing indikator, selanjutnya dilakukan pembobotan pada variabel. Output dari pembobotan antar variabel ini akan dijadikan input untuk menentukan prioritas pengembangan pada kawasan Jembatan Surabaya. Output analisis AHP pada pembobotan antar variabel adalah sebagai berikut (Gambar 5).
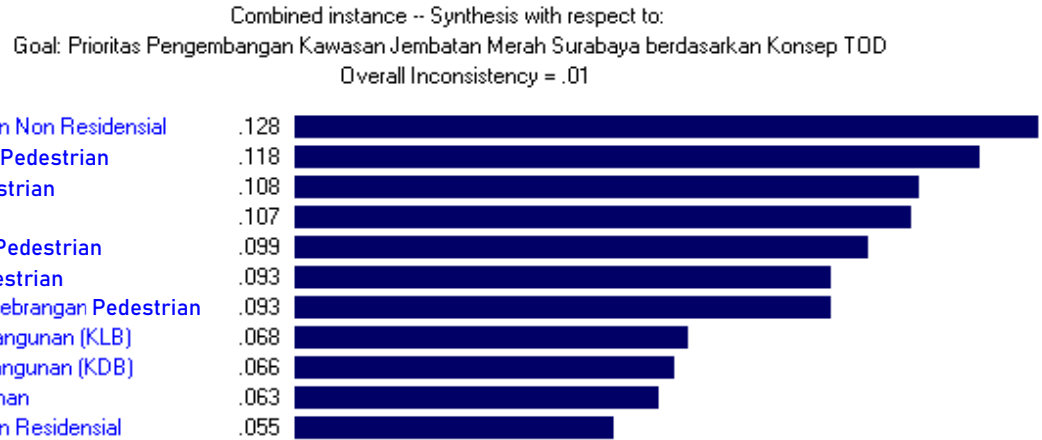

Gambar 5. Output Variabel Prioritas Pengembangan di Kawasan Jembatan Merah Surabaya

Pada grafik output di atas, terlihat runtutan bobot dari yang tertinggi hingga terendah. Variabel dengan bobot tertinggi merupakan variabel yang paling diprioritaskan pengembangannya. Dapat disimpulkan bahwa urutan variabel yang paling 
diprioritaskan dalam pengembangan kawasan Jembatan Merah Surabaya berdasarkan konsep TOD adalah sebagai berikut (Tabel 5).

Tabel 5. Proritas Pengembangan Kawasan Jembatan Merah Surabaya berdasarkan Konsep TOD

\begin{tabular}{cc} 
Prioritas & Variabel \\
\hline Prioritas ke 1 & Penggunaan Lahan Non-residensial \\
Prioritas ke 2 & Ketersediaan Jalur Pedestrian \\
Prioritas ke 3 & Kondisi Jalur Pedestrian \\
Prioritas ke 4 & Kondisi Bangunan \\
Prioritas ke 5 & Konektivitas Jalur Pedestrian \\
Prioritas ke 6 & Dimensi Jalur Pedestrian \\
Prioritas ke 7 & Ketersediaan Penyebrangan Pedestrian \\
Prioritas ke 8 & KLB (Koefisien Lantai Bangunan) \\
Prioritas ke 9 & KDB (Koefisisen Dasar Bangunan) \\
Prioritas ke 10 & Kepadatan Bangunan \\
Prioritas ke 11 & Penggunaan Lahan Residensial \\
\hline
\end{tabular}

Dari tabel tersebut dapat disimpulkan bahwa variabel penggunaan lahan non-residensial menjadi prioritas tertinggi dalam pengembangan kawasan Jembatan Merah Surabaya. Menurut para stakeholder, penggunaan lahan non-residensial ini sangat penting dalam pengembangan kawasan TOD. Dengan adanya penggunaan lahan bercampur diharapkan dapat meningkatkan intensitas pergerakan manusia di dalamnya, sehingga dapat mempengaruhi demand akan transportasi publik pada kawasan.

\subsection{IDENTIFIKASI KARAKTERISTIK KAWASAN JEMBATAN MERAH SURABAYA SESUAI KRITERIA KAWASAN TOD}

Dalam sasaran, ini dilakukan dua tahap analisis, yakni analisis karakteristik kondisi eksisting wilayah dengan kesesuaiannya terhadap kriteria TOD yang telah ditentukan, serta analisis nilai kesesuaiannya terhadap kriteria TOD yang telah ada. Tabel 6 merupakan hasil analisis tersebut yang dikelompokkan berdasarkan indikatornya yakni Density, Diversity, dan Design.

Tabel 6. Kesesuaian Setiap Variabel pada Indikator Density di Kawasan Jembatan Merah Surabaya dengan Kriteria TOD

\begin{tabular}{|c|c|c|c|c|c|}
\hline Variabel & Parameter TOD & Blok & Karakteristik Kawasan & Kesesuaian & Nilai Kesesuaian \\
\hline KDB (Koefisien Dasar & Minimal 70\% (bangunan & 1 & $86.32 \%$ & $\mathrm{~S}$ & $123,31 \%$ \\
\hline \multirow{3}{*}{ Bangunan) } & cagar budaya, & 2 & $85 \%$ & S & $121,43 \%$ \\
\hline & memperhatikan & 3 & $77.5 \%$ & S & $110,71 \%$ \\
\hline & golongannya) & 4 & $83.2 \%$ & S & $118,86 \%$ \\
\hline KLB (Koefisien Lantai & Minimal 3,0 (bangunan & 1 & 2,3 & TS & $76,6 \%$ \\
\hline \multirow[t]{3}{*}{ Bangunan) } & cagar budaya, & 2 & 2,7 & TS & $90 \%$ \\
\hline & memperhatikan & 3 & 3,66 & S & $86,3 \%$ \\
\hline & golongannya) & 4 & 2,6 & TS & $86,6 \%$ \\
\hline \multirow[t]{4}{*}{ Kepadatan Bangunan } & Minimal 40 bangunan/hektar & 1 & 50 bagunan $/ \mathrm{Ha}$ & S & $135 \%$ \\
\hline & & 2 & 33 bagunan/Ha & TS & $82.5 \%$ \\
\hline & & 3 & 22 bagunan/Ha & TS & $55 \%$ \\
\hline & & 4 & 22 bagunan/Ha & TS & $55 \%$ \\
\hline
\end{tabular}

Keterangan: S (Sesuai); TS (Tidak Sesuai)

Tabel 7. Rata-Rata Nilai Kesesuaian Indikator Density di Kawasan Jembatan Merah Surabaya

\begin{tabular}{ccccc}
\hline Blok & KDB & KLB & Kepadatan Bangunan & Nilai Kesesuaian \\
\hline Blok 1 & $123,31 \%$ & $76,6 \%$ & $135 \%$ & $111,64 \%$ \\
Blok 2 & $121,43 \%$ & $90 \%$ & $82.5 \%$ & $97,98 \%$ \\
Blok 3 & $110,71 \%$ & $86,3 \%$ & $55 \%$ & $84,03 \%$ \\
Blok 4 & $118,86 \%$ & $86,6 \%$ & $55 \%$ & $86.82 \%$ \\
\hline
\end{tabular}


Dari hasil perhitungan rata-rata yang ditunjukkan pada Tabel 7 , diketahui bahwa nilai kesesuaian paling tinggi pada indikator density yaitu pada blok 1 dengan nilai kesesuaian KDB dan KLB yang telah melebihi $100 \%$. Sedangkan blok dengan nilai terendah adalah blok 3.

Tabel 8. Kesesuaian Setiap Variabel pada Indikator Diversity di Kawasan Jembatan Merah Surabaya dengan Kriteria TOD

\begin{tabular}{lccccc}
\multicolumn{1}{c}{ Variabel } & Parameter TOD & Blok & Karakteristik Kawasan & Kesesuaian & Nilai Kesesuaian \\
\hline Penggunaan Lahan & $30 \%$ dari luas kawasan & 1 & $42 \%$ & TS & $71,42 \%$ \\
Residensial & & 2 & $0 \%$ & TS & $0 \%$ \\
& & 3 & $24 \%$ & TS & $80 \%$ \\
& & $32 \%$ & TS & $93,75 \%$ \\
Penggunaan Lahan Non- & \multirow{2}{*}{ 70\% dari luas kawasan } & 1 & $58 \%$ & & \\
Residensial & & 2 & $100 \%$ & TS & $82,85 \%$ \\
& & 3 & $76 \%$ & $70 \%$ \\
& & $68 \%$ & TS & $92,10 \%$ \\
\end{tabular}

Keterangan: S (Sesuai); TS (Tidak Sesuai)

Tabel 9. Rata-Rata Nilai Kesesuaian Indikator Diversity di Kawasan Jembatan Merah Surabaya

\begin{tabular}{cccc}
\hline Blok & Penggunaan Lahan Residensial & Penggunaan Lahan Non-Residensial & Nilai Kesesuaian \\
\hline Blok 1 & $71,42 \%$ & $82,85 \%$ & $77,14 \%$ \\
Blok 2 & $0 \%$ & $70 \%$ & $35 \%$ \\
Blok 3 & $80 \%$ & $92,1 \%$ & $86,05 \%$ \\
Blok 4 & $93,75 \%$ & $97,14 \%$ & $95,44 \%$ \\
\hline
\end{tabular}

Tabel 8 dan Tabel 9 menunjukkan bahwa kesesuian yang paling tinggi untuk indikator diversity terdapat pada blok 4. Hal ini terjadi karena blok 4 memiliki penggunaan lahan bercampur dengan persentase proporsi lahan yang mendekati standar kawasan TOD yakni residensial sebesar $30 \%$ dan non-residensial sebesar $70 \%$. Adapun nilai kesesuaian terendah yaitu blok 2 karena pada blok ini tidak terdapat sama sekali penggunaan lahan residensial.

Tabel 10. Kesesuaian Setiap Variabel pada Indikator Design di Kawasan Jembatan Merah Surabaya dengan Kriteria TOD

\begin{tabular}{|c|c|c|c|c|c|}
\hline Variabel & Parameter TOD & Blok & Karakteristik Kawasan & Kesesuaian & Nilai Kesesuaian \\
\hline Ketersediaan & Ketersediaan & 1 & $67 \%$ & TS & $67 \%$ \\
\hline \multirow[t]{3}{*}{ Jalur Pedestrian } & Pedestrian 100\% & 2 & $25 \%$ & TS & $25 \%$ \\
\hline & & 3 & $89 \%$ & TS & $89 \%$ \\
\hline & & 4 & $49 \%$ & TS & $49 \%$ \\
\hline \multirow[t]{4}{*}{ Kondisi Jalur Pedestrian } & Tersedia & 1 & Belum menyeluruh & TS & $0 \%$ \\
\hline & penerangan dan bollard, & 2 & Belum menyeluruh & TS & $25 \%$ \\
\hline & fasilitas peneduh, dan & 3 & Belum menyeluruh & TS & $0 \%$ \\
\hline & tactile & 4 & Belum menyeluruh & TS & $0 \%$ \\
\hline \multirow[t]{4}{*}{ Dimensi Jalur Pedestrian } & Minimal 2 meter & 1 & 2-2,5 meter & S & $108 \%$ \\
\hline & & 2 & 2-2,5 meter & S & $112,5 \%$ \\
\hline & & 3 & 1-3 meter & TS & $75 \%$ \\
\hline & & 4 & 1,5-3 meter & TS & $105 \%$ \\
\hline Konektivitas Jalur & Waktu tempuh 5-10 menit & 1 & 8,8 & S & $113 \%$ \\
\hline \multirow[t]{3}{*}{ Pedestrian } & dari titik transit & 2 & 10,4 & TS & $96 \%$ \\
\hline & & 3 & 8,14 & S & $112.85 \%$ \\
\hline & & 4 & 11,81 & TS & $84.67 \%$ \\
\hline Ketersediaan & Bebas pembatas & 1 & Belum tersedia & TS & $0 \%$ \\
\hline \multirow[t]{3}{*}{ Penyebrangan Pedestrian } & & 2 & Bebas pembatas & $\mathrm{S}$ & $100 \%$ \\
\hline & & 3 & Bebas pembatas & S & $100 \%$ \\
\hline & & 4 & Bebas pembatas & S & $100 \%$ \\
\hline
\end{tabular}




\begin{tabular}{cccccc}
\hline Variabel & \multicolumn{1}{c}{ Parameter TOD } & Blok & Karakteristik Kawasan & Kesesuaian & Nilai Kesesuaian \\
\hline Kondisi Bangunan & $\begin{array}{l}\text { Bangunan memiliki ciri, } \\
\text { kondisi fisik baik dan fasad } \\
\text { bervariasi }\end{array}$ & 1 & $\begin{array}{l}\text { Bangunan masih kokoh, } \\
\text { fasad monoton } \\
\text { Bangunan rapuh, fasad } \\
\text { monoton }\end{array}$ & TS & $50 \%$ \\
& 2 & $\begin{array}{c}\text { Bangunan rapuh, fasad } \\
\text { monoton } \\
\text { monoton }\end{array}$ & TS & TS & $25 \%$ \\
\hline
\end{tabular}

Keterangan: S (Sesuai); TS (Tidak Sesuai)

Tabel 11. Rata-Rata Nilai Kesesuaian Indikator Design di Kawasan Jembatan Merah Surabaya

\begin{tabular}{cccccccc} 
Blok & $\begin{array}{c}\text { Ketersediaan } \\
\text { Jalur } \\
\text { Pedestrian }\end{array}$ & $\begin{array}{c}\text { Kondisi Jalur } \\
\text { Pedestrian }\end{array}$ & $\begin{array}{c}\text { Konektivitas } \\
\text { Jalur } \\
\text { Pedestrian }\end{array}$ & $\begin{array}{c}\text { Dimensi } \\
\text { Jalur } \\
\text { Pedestrian }\end{array}$ & $\begin{array}{c}\text { Ketersediaan } \\
\text { Penyebrangan } \\
\text { Jalur Pedestrian }\end{array}$ & $\begin{array}{c}\text { Kondisi } \\
\text { Bangunan }\end{array}$ & $\begin{array}{c}\text { Rata-rata } \\
\text { Nilai } \\
\text { Kesesuaian }\end{array}$ \\
\hline Blok 1 & $67 \%$ & $0 \%$ & $113 \%$ & $108 \%$ & $0 \%$ & $50 \%$ & $56,3 \%$ \\
Blok 2 & $25 \%$ & $25 \%$ & $96 \%$ & $112,5 \%$ & $100 \%$ & $25 \%$ & $63,91 \%$ \\
Blok 3 & $89 \%$ & $0 \%$ & $112.85 \%$ & $75 \%$ & $100 \%$ & $25 \%$ & $66,98 \%$ \\
Blok 4 & $49 \%$ & $0 \%$ & $84.67 \%$ & $105 \%$ & $100 \%$ & $25 \%$ & $60,61 \%$ \\
\hline
\end{tabular}

Dari hasil analisis kesesuaian yang dilakukan (Tabel 10 dan Tabel 11), diketahui bahwa pada tiap blok di kawasan Jembatan Merah Surabaya kebanyakan belum sesuai dengan standar kondisi bangunan jika dilihat dari fisik bangunannya karena banyak bangunan yang sudah rapuh. Lalu jika dilihat dari variasi fasadnya, bangunan pada tiap blok umumnya juga cenderung monoton dan warna cat nya sudah kusam. Hal ini menunjukkan belum adanya kesesuaian dengan standar kondisi bangunan yang harus tersedia pada kawasan TOD. Oleh karena itu, nilai kesesuaiannya tidak ada yang mencapai $100 \%$.

Setelah mengetahui nilai kesesuaian setiap indikator pada setiap blok terhadap standar (parameter) minimal kawasan TOD, dilakukan kalkulasi tingkat kesesuaian secara menyeluruh dengan menggunakan kalkulasi rata-rata nilai kesesuaian dari ketiga indikator yakni density, diversity, dan design). Berikut merupakan tabel hasil kalkulasinya (Tabel 12).

Tabel 12. Rata-Rata Nilai Kesesuaian di Setiap Blok pada Kawasan Jembatan Merah Surabaya

\begin{tabular}{ccccc} 
Blok & $\begin{array}{c}\text { Density (Kepadatan } \\
\text { Kawasan) }\end{array}$ & $\begin{array}{c}\text { Diversity (penggunaan } \\
\text { Lahan Bercampur) }\end{array}$ & $\begin{array}{c}\text { Design (Pedestrian } \\
\text { Friendly) }\end{array}$ & $\begin{array}{c}\text { Rata-rata Nilai } \\
\text { Kesesuaian }\end{array}$ \\
\hline Blok 1 & $111,64 \%$ & $72,55 \%$ & $56,3 \%$ & $80,16 \%$ \\
Blok 2 & $97,98 \%$ & $35 \%$ & $63,91 \%$ & $65,63 \%$ \\
Blok 3 & $84,03 \%$ & $86,05 \%$ & $66,98 \%$ & $79,02 \%$ \\
Blok 4 & $86.82 \%$ & $95,44 \%$ & $60,61 \%$ & $80,96 \%$ \\
\hline
\end{tabular}

Dari tabel tersebut dapat disimpulkan bahwa pada tiap blok di kawasan Jembatan Merah Surabaya, masih belum sesuai dengan kriteria kawasan TOD. Nilai kesesuainnya pun bervariasi. Namun nilai kesesuaian paling rendah didapati pada blok 2 , yakni hanya sebesar $52,40 \%$. Sedangkan untuk blok 1,3 , dan 4 besar nilai kesesuainnya hampir sama, yakni $80,16 \%$ untuk blok $1,79,01 \%$ untuk blok 3 , dan 80,96\% untuk blok 4 .

Sedangkan jika dilihat dari rata-rata kesesuaian tiap indikator terhadap kriteria TOD pada kawasan adalah sebagai berikut (Tabel 13).

Tabel 13. Rata-rata Nilai Kesesuaian di Setiap Indikator pada Kawasan Jembatan Merah Surabaya

\begin{tabular}{|c|c|c|c|}
\hline Blok & $\begin{array}{l}\text { Density (Kepadatan } \\
\text { Kawasan) }\end{array}$ & $\begin{array}{l}\text { Diversity (Penggunaan } \\
\text { Lahan Bercampur) }\end{array}$ & Design (Pedestrian Friendly) \\
\hline Blok 1 & $111,64 \%$ & $72,55 \%$ & $56,3 \%$ \\
\hline Blok 2 & $97,98 \%$ & $35 \%$ & $63,91 \%$ \\
\hline Blok 3 & $84,03 \%$ & $86,05 \%$ & $66,98 \%$ \\
\hline Blok 4 & $86,82 \%$ & $95,44 \%$ & $60,61 \%$ \\
\hline $\begin{array}{c}\text { Rata-Rata Nilai Kesesuaian } \\
\text { pada Kawasan }\end{array}$ & $95,12 \%$ & $72,26 \%$ & $61.95 \%$ \\
\hline
\end{tabular}


Dari tabel di atas disimpulkan bahwa semua indikator pada kawasan, yakni density, diversity, serta design belum sesuai dengan kriteria kawasan TOD karena nilai rata-rata kesesuaiannya belum mencapai 100\%. Dapat disimpulkan juga bahwa indikator yang memiliki nilai kesesuaian terendah adalah indikator design dengan rata-rata nilai $61,95 \%$. Sedangakan untuk nilai kesesuaian indikator diversity berada di urutan kedua dengan persentase kesesuaian sebesar $72,26 \%$ dan nilai kesesuaian tertinggi didapatkan oleh indikator density, yakni 95,12\%.

\section{KESIMPULAN}

Dari hasil penelitian, ditemukan tiga indikator yang digunakan dalam penelitian, yaitu Density (Kepadatan Kawasan), Diversity (Penggunaan Lahan), dan Design (Pedestrian Friendly). Dari ketiga indikator tersebut, bobot paling tinggi didapatkan oleh indikator Diversity dengan bobot 0,408 atau 40,8\%, lalu indikator Design dengan bobot 0,376 atau 37,6\%, dan yang terakhir adalah indikator Density dengan bobot 0,216 atau 21,6\%. Semakin tinggi bobot berarti semakin penting pula indikator atau variabel tersebut didahulukan dalam pengembangannya. Tiga indikator tersebut kemudian dijabarkan menjadi sebelas variabel yang dijadikan kriteria kawasan TOD untuk merumusan prioritas pengembangan kawasan Jembatan Merah Surabaya.

Dari ketiga indikator tersebut terdapat sebelas variabel dengan urutan prioritas pengembangannya, yakni: Penggunaan Lahan Non-Residensial; Ketersediaan Jalur Pedestrian; Kondisi Jalur Pedestrian; Kondisi Bangunan; Konektivitas Jalur Pedestrian; Dimensi Jalur Pedestrian; Ketersediaan Penyebrangan Pedestrian; KLB (Koefisien Lantai Bangunan); KDB (Koefisien Dasar Bangunan); Kepadatan Bangunan dan Penggunaan Lahan Residensial. Dari hasil penelitian, ditemukan satu variabel baru yang belum pernah digunakan dalam penelitian sebelumnya, yakni variabel "Kondisi Bangunan" yang masuk di dalam indikator "Design (Pedestrian Friendly)". Variabel ini didapatkan dari hasil sintesa pustaka dan juga telah dikonfirmasi sebagai variabel yang berpengaruh oleh para stakeholder dalam pengembangan kawasan Jembatan Merah Surabaya berdasarkan konsep TOD. Variabel Kondisi Bangunan dianggap sangat berpengaruh terhadap citra kawasan dan dipertimbangkan karena kawasan Jembatan Merah Surabaya memiliki potensi utama, yakni bangunan cagar budayanya. Sehingga pengembangan kondisi bangunan cagar budaya ini diharapkan dapat membentuk citra kawasan yang memiliki ciri khas dan menjadi daya tarik orang yang datang ke kawasan. Maka dari itu, dengan adanya kondisi bangunan yang baik ini, diharapkan dapat meningkatkan kenyamanan para pejalan kaki.

Selanjutnya, jika dibandingkan dengan hasil analisis kesesuaian dan nilai kesesuaian kondisi kawasan saat ini dengan kriteria konsep TOD, dapat disimpulkan bahwa nilai kesesuaian terendah didapatkan oleh blok 2. Rata-rata nilai kesesuaian blok 2 terhadap kriteria kawasan TOD hanya 65,63\% dengan rincian nilai kesesuaian untuk indikator density sebesar 97,98\%, diversity $35 \%$, dan design $63,91 \%$. Hal ini berarti diperlukan adanya upaya peningkatan pengembangan hingga $44,37 \%$ dari kondisi eksisting khususnya pada indikator diversity dan design yang nilai kesesuaiannya masih terhitung jauh dari kriteria kawasan TOD yang ada.

Lalu, jika diperhatikan dari rata-rata nilai kesesuaian ketiga inidikator pada kawasan, nilai terendah didapatkan oleh indikator Design (Pedestrian Friendly) dengan persentase kesesuaian 61,95\%. Sedangakan untuk nilai kesesuaian indikator Diversity (Penggunaan Lahan Bercampur) berada di urutan kedua dengan persentase kesesuaian sebesar $72,26 \%$ dan nilai kesesuaian tertinggi didapatkan oleh indikator Density (Kepadatan Kawasan), yakni 85,19\%. Semakin rendah kesesuaian berarti semakin besar gap kesesuaian antara indikator tersebut pada kondisi eksisting terhadap kriteria kawasan TOD.

Maka dari itu, dari hasil penelitian di atas dapat disimpulkan bahwa prioritas pengembangan kawasan Jembatan Merah Surabaya menggunakan konsep TOD bisa diurutkan dari prioritas pengembangan menurut para stakeholder dari hasil analisis AHP, namun juga perlu memperhatikan pula besar nilai kesesuaian indikator pada tiap blok. Dari situ, diharapkan dapat tersusunnya pengembangan kawasan Jembatan Merah Surabaya dengan konsep TOD yang terstruktur dan sesuai dengan kebutuhan.

\section{UCAPAN TERIMAKASIH}

Puji syukur penulis sampaikan kepada semua pihak yang telah membantu dan membimbing penulis hingga penulis dapat menyelesaikan jurnal yang berjudul "Prioritas Pengembangan Kawasan Jembatan Merah Surabaya berdasarkan Konsep 
Transit Oriented Development. Ucapan terima kasih penulis sampaikan kepada para responden, yakni pihak dari Badan Perencanaan Pembangunan Kota Surabaya (Bappeko), Dinas Perumahan Rakyat dan Kawasan Permukiman, Cipta Karya dan Tata Ruang Kota Surabaya (DPRKP-CKTR), Dinas Perhubungan Kota Surabaya (Dishub), dan Dinas Pariwisata dan Kebudayaan Kota Surabaya (Disbudpar).

\section{DAFTAR PUSTAKA}

Bappeko Surabaya. (2018). SMART : Surabaya Integrated Mass Rapid Transit. Surabaya.

Calthorpe Associates. (2011). Transit-Oriented Development Design Guidelines. San Diego: Calthorpe Associates. Diakses dari https://planning.saccounty.net/PlansandProjectsIn-Progress/Documents/General Plan 2030/GP Elements/TOD Guidelines.pdf

Cervero, R., \& Day, J. (2018). Suburbanization and Transit-Oriented Development in China. Transport Policy, 15(5), 315-323. https://doi.org/10.1016/j.tranpol.2008.12.011

City of Winnipeg. (2011). Winnipeg Transit-Oriented Development Handbook. Winnipeg: PB's Place Making Group. Diakses dari https://www.winnipeg.ca/ppd/Documents/CityPlanning/PoliciesGuidelinesStudies/Transit-Oriented-Development-Handbook.pdf

Curtis, C., Renne, J. L., \& Bertolini, L. (2009). Transit Oriented Development: Making It Happen. Farnham: Ashgate.

Dittmar, H., \& Ohland, G. (2004). The New Transit Town: Best Practices in Transit Oriented Development. Washington: Island Press.

Florida Department of Transportation. (2012). Florida TOD Guidebook. Florida. Diakses dari https://issuu.com/floridanotallaboard/docs/florida_tod_guidebook-sm_1_

Institute for Transportation and Development Policy. (2017). TOD Standard. New York: ITDP. Diakses dari www.ITDP.org

Peraturan Daerah Kota Surabaya Nomor 5 Tahun 2005 Tentang Pelestarian Bangunan dan/atau Lingkungan Cagar Budaya.

Peraturan Menteri ATR/KaBPN No. 16 Tahun 2017 tentang Pedoman Pengembangan Kawasan Berorientasi Transit.

Peraturan Menteri PU No.3 Tahun 2014 tentang Pedoman Perencanaan, Penyediaan, dan Pemanfaatan Prasarana dan Sarana jaringan Pejalan Kaki di Kawasan Perkotaan.

Renne, J., \& Listokin, D. (2016). Guide to Facilitate Historic Preservation through Transit-Oriented Development. Diakses dari https://groups.tti.tamu.edu/communications/files/2016/10/TOD-and-HP-Guidebook-v11-HRhyperlinks.pdf

Undang-undang Republik Indonesia Nomor 11 Tahun 2010 tentang Cagar Budaya.

Watson, D., Plattus, A. J., \& Shibley, R. G. (2003). Time-Saver Standards for Urban Design. New York: McGraw-Hill.

Winkelman, S. (2014). Transit Oriented Development: What? Why? and How? MAIN-LAC Dialogue. Washington: Center for Clean Air Policy. 